\title{
The value of commercial fish size distribution recorded at haul by haul compared to trip by trip
}

\author{
Plet-Hansen Kristian S ${ }^{1,{ }^{*}}$, Bastardie François ${ }^{1}$, Ulrich Clara ${ }^{1,2}$
}

\author{
1 Technical University of Denmark, National Institute of Aquatic Resources (DTU Aqua), Kemitorvet, \\ 2800 Kgs, Lyngby, Denmark \\ 2 IFREMER, Centre Atlantique, Rue de I'lle d'Yeu, BP 21105, 44311 Nandes Cedex 03, France \\ * Corresponding author : Kristian S. Plet-Hansen, email address : $\underline{\text { kspl@aqua.dtu.dk }}$
}

\begin{abstract}
:
Data from commercial fishing vessels may enhance the range of observations available for monitoring the marine environment. However, effort and catch data provide information on fish distribution with a bias due to spatial targeting and selectivity. Here, we measured the shortcomings of standard fisherydependent data and advocate for the utilization of more precise datasets indirectly collected by the commercial fishery. Data from a Danish traceability system, which records size of commercial fish at the haul level, are held against the set-up of current eLog and sales slips' data collected for the Danish fisheries. We showed that the most accurate mapping of the spatial distribution of catches per size group is not only possible through size records collected at the haul level but also by high resolution on fishing effort data. In Europe, the regulation to land all catches with a quota or minimum size limit, including unwanted, has increased the focus on avoidance and discards; we show the potential of such data sources to inform on fish abundance and distribution, especially of importance where fishery-dependent data are the only source of information.
\end{abstract}

Keywords : electronic monitoring, sea-packing commercial fishery data, spatial analysis, spatial scale, species size distribution 
27 In many areas, commercial fishers are required to declare the landed amount of species in official logbooks. Since 2015, EU vessels must report landings in weight in the logbooks for each haul, or as a minimum once every 24 hours (EU, 2012). Additionally, EU vessels above 12 meters in length are required to carry a Vessel Monitoring System (VMS) (EU, 2011) which transmit time, position, speed and course of the vessel at predefined time intervals. By coupling logbook and VMS data, it is possible to estimate the spatial and temporal distribution of landings by species (Bastardie et al., 2010; Gerritsen and Lordan, 2011). However, the entry format of logbooks only provides knowledge on the species, not the body sizes of the fish (EU, 2011). Concurrently, along assessing the status of the marine fish species, scientific surveys conducted by research vessels do collect species and size information at a fine spatial scale. However, the temporal coverage and data quantity are much lower for survey data than commercial fisheries data that pose challenges in using them for widescale mapping of fish (Pennino et al., 2016; Bourdaud et al., 2017).

In a fisheries management context, the objective of the measures is to limit the fishery within predefined objectives (Hilborn, 2007). For such purpose, more detailed information of the catch composition including size of the fish at the actual fishing event ('haul' for active gears) may allow for better adaptations of management measures, at least in regions like the EU where the on-board observer coverage is closer to $1 \%$ than to $100 \%$ (Little et al., 2015; James et al., 2019). The full implementation of the European landing obligation in 2019 (EU, 2013; Salomon et al., 2014) further increases the need for more detailed information as the fisheries adapt to the regulation, by increasing fishing gear selectivity e.g. with mesh size changes, grid panels or LED lights on gear (O’Neill et al., 
2019), or by avoiding the hotspots of unwanted fish spatially, which is also a way of making the fishing more selective (Little et al., 2015; Reid et al., 2019). Although certain species are always unwanted, some target species can also become unwanted e.g., in the case where the allocated quota is close to being exhausted (Borges and Penas Lado, 2019), or the encountered fish are undersized and therefore not marketable (Catchpole et al., 2018; Villasante et al., 2019), or simply because fishers have expectations on market preferences for certain species or sizes (Ono et al., 2013; Batsleer et al., 2015). Conversely, some bycatches may be wanted because they act as a bonus on top of the regular targeted species (Mortensen et al., 2018). Therefore, being able to locate where the species population distribute and where its unwanted components are located, especially the undersized fish, is of importance to help achieve a more selective fishing (STECF, 2018) while maintaining the profitability of the fishery. Tailoring the avoidance of unwanted fish depends on the individual vessel, and the species and fishing grounds may at times translate into subtle tactical avoidance measures based on empirical experience at sea. For example, Mortensen et al. (2018) described some avoidance tactics used by individual fisher, some of which may appear counterintuitive: if large amount of saithe (Pollachius virens) are caught in a haul, the best approach might simply be to continue with a new haul at the same heading as the previous, on the basis that the previous haul had passed through the school of saithe, whereby a new haul in the same transect would likely be after the school.

Tools such as averaged species distribution maps can assist the fishermen in optimizing their fishing tactics at a larger scale (Little et al., 2015; Reid et al., 2019; Robert et al., 2019). But at the scale of the individual fishing operation, better knowledge on the size distribution of target species may not only help spatial avoidance but could also increase the profit of fishing, in the situation of limited overall catch allowance, because of higher prices per $\mathrm{kg}$ fish landed.

The current data level in eLog reporting is at the haul level and sales slips' information from landings in port. This mean that any size information is collected at the level of the full fishing trip (EU, 2011, 
2016). This trip-level information can be redistributed back to the haul level by using the size composition of each species for the fishing trip, under the assumption that size composition at the trip-level reflects the size composition at the haul level (Plet-Hansen et al., 2018). Possible discrepancies when deducing spatial distribution from analysing commercial fishing data might not be an issue when using data from small-scale vessels which perform only few hauls within short distance, but could be pronounced for large-scale vessels conducting several hauls per day and weeklong fishing trips, making a mismatch between trip and haul fish size composition highly likely. In this study, we investigated this possible mismatch by using a recent commercial fisheries system collecting at-sea observations of species and their commercial size class from grading machines onboard vessels. We test whether a difference exists in terms of the false presence of certain size classes at the haul level, estimate the impact of the level of spatial resolution for data aggregation based on trip-level records and investigate the potential bias that would arise from the chosen grid cell size and shape (Dark and Bram, 2007).

\section{Material and methods}

\section{At-sea grading machine, SIF data}

The Danish "Sporbarhed I Fiskerisektoren" (SIF) database contains information on haul positions and times derived from fishers entries in their electronic logbook (eLog) and landed amount in $\mathrm{kg}$ of each commercial size class by species derived from records by on-board grading machines on the vessel. It has been mandatory for Danish fishing vessels to fill in their eLog for each since 2015 (Miljø- og Fødevareministeriet, 2014). SIF therefore contain landings of species and their commercial size classes together with positional data at a haul-by-haul level. Commercial size classification follows the requirements of the EU (EU, 1996). Plet-Hansen et al. (2018) previously described the 
SIF dataset in details and investigated its usefulness for scientific purposes through comparison to logbook and sales slips data. The dataset was considered suitable for further scientific analyses, notwithstanding some variability in data quality across years, vessels, species and size classes (PletHansen et al. 2018).

In the present study we used SIF data from 10,092 hauls from six vessels over the period 2015-2017, for which the quality was deemed high for the following 12 species: cod (Gadus morhua), haddock (Melanogrammus aeglefinus), hake (Merluccius merluccius), lemon sole (Microstomus kitt), ling (Molva molva), monkfish (Lophius spp.), pollack (Pollachius pollachius), saithe (Pollachius virens), turbot (Scophthalmus maximus), witch flounder (Glyptocephalus cynoglossus), wolffish (Anarhichas spp.) and whiting (Merlangius merlangus) (Table 1). These 12 species constituted $76.5 \%$ of the total landings in value and $67.1 \%$ of the total landings in weight for the three years for these six vessels. The final dataset after the validation according to Plet-Hansen et al., 2018 is the baseline for comparison as records of species and sizes are directly available at the individual haul level. The dataset is henceforth referred to as "SIF".

\section{Trip-level reconstructed data}

In order to estimate the gain of having size class recorded at the haul level, we calculated a second dataset from aggregating the SIF data to mimic the level of aggregation of standard logbooks data. In this second dataset, we aggregated the weight of the specific size classes for each of the 12 species in SIF to the trip level, as this is the stage at which size class information can be derived from vessels without on-board grading machines in Denmark. We calculated the full landing of each species for each haul, disregarding the size class information to mimic the entry format in the eLog. We then reallocated the average size composition aggregated at the trip-level for each species back to the full landings of each species at each haul. Thereby, this second dataset has the size class information as 
if it had been then the trip-level origin of size records (TOR). TOR thus represents the size class information that can be collected under the current limitation of size class information at the trip level, while full species composition information is available at the haul level from the eLog. Giving an example for illustration: Two hauls recorded in SIF, one with $2 \mathrm{~kg}$ of size class 5 cod and one with 8 $\mathrm{kg}$ of size class $1 \mathrm{cod}$ will in TOR result in two hauls that both have size class 5 and size class 1 recorded. However, in TOR the first haul will have $0.4 \mathrm{~kg}$ of size class 5 cod and $1.6 \mathrm{~kg}$ of size class $1 \mathrm{cod}$ and the second haul will have $1.6 \mathrm{~kg}$ of size class 5 cod and $6.4 \mathrm{~kg}$ of size class 1 cod. The reason for this is that the TOR dataset is created under the assumption that the trip level size composition is the same as the haul level size composition. There, the percentage of size class 5 cod and the percentage for size class 1 cod for the full trip (20\% for size class 5 and $80 \%$ for size class 1 ) will be redistributed back to the hauls as if the percentwise size composition for the trip also is the percentwise size composition for each haul.

\section{Estimation of difference between SIF and TOR}

For each haul, we calculated the difference between SIF and TOR by weight in landings of each species and size class and we aggregated size classes into two overall groups for each species ("small fish" and "large fish") in order to reduce the number of categories and amplify the potential differences between the datasets. Such a small/large fish division can be based on different factors, such as age and maturity. Here we used the price difference as the main factor (Sjöberg, 2012; Hoff et al., 2019). Because SIF data is commercial data and is influenced by the expected price of the sold fish, the separation was based on the economic value of the size classes for each species. The mean price per commercial size classes was calculated on SIF for the study period 2015-2017. The threshold under which size classes at the fish market are perceived as "small" was defined at the point where the value of the fish drops. Additionally, we used literature indicating size class and economic effect on discarding practices as an extra indication to help validate this threshold (Table 2). Hence, 
for cod, haddock, hake, saithe, pollack, whiting, ling and lemon sole these divisions coincide with 75-100\% expected maturity of the fish (Silva et al., 2013; ICES, 2014a, 2014b, 2014c, 2014d; Macdonald et al., 2017; FishBase, 2019a). For monkfish, turbot, wolffish and witch flounder the maturity at division between "small" and "large" is uncertain but likely less than $50 \%$, potentially as low as 0\% (Bowering, 1976; Robinson et al., 2010; Gunnarsson et al., 2013; Silva et al., 2013; Macdonald et al., 2017; FishBase, 2019b; The Safina Center, 2019).

When using fisheries-dependent data from active fishing gear types, each haul can be viewed as a data sampling transect. Every haul containing a species and size class thereby becomes a record of presence. An analysis of fish presence/absence between SIF and TOR data setup was made to estimate possible 'false presence' samples (hauls) occurring when size class information from trip-level is redistributed to the haul-level. Haul locations were assigned to grid cells of $0.1^{\circ}$ latitude by $0.2^{\circ}$ longitude representing ca. $121 \mathrm{~km}^{2}$ at the study area latitude (North Sea region). The grid cell size was decided based on two factors. i) the average distance of hauls ( $17 \mathrm{~km} \mathrm{~N} / \mathrm{S}$ and $\sim 16 \mathrm{~km} \mathrm{E} / \mathrm{W})$, meaning that an average haul would not cross through more than two or three grid cells. ii) to comply with regulation protecting the confidentiality of individual vessels data on the fine-scale and infrequent fishing grounds. Each haul is thereby treated as a transect passing through a grid cell. Because only the total amount caught per haul in this dataset is known and therefore the exact timing of each caught fish within the haul is unknown, the landed amount from each haul is treated as equally likely to originate from any grid cell in which the haul passed through. The share of 'false presence' samples was calculated for each species and size grouping as presence records in TOR where no presences occurred in SIF, divided by the total number of hauls passing through the grid cell.

To evaluate the degree of discrepancy between SIF and TOR when describing the spatial patterns of landed amounts of fish sizes, and the effect of the grid cell resolution, we used the SPAtial EFficiency metric (SPAEF) introduced in (Koch et al., 2018). SPAEF is calculated as: 
where $\alpha$ is the Pearson correlation coefficient between SIF and TOR grid values, $\beta$ is the coefficient of variation for SIF grid values divided by the coefficient of variation for TOR grid values and $\gamma$ is the histogram overlap between the grid patterns with SIF values and grid patterns with TOR values. SPAEF is thereby a multi-composite and statistical metric that summarizes the degree of matching of two spatial patterns in one single value (between $-\infty$ and 1 where 1 is full overlap) based on the balancing between multiple components from where the spatial comparison can be made, an approach which has been advocated for among geoscientists (Krause et al., 2005; Gupta et al., 2012; Koch et $a l ., 2018)$. While the topic for which this metric has been developed is not within the field of fisheries, the metric should be universal for spatial analysis and apply to any spatially distributed data such as delocalized recording of fish catches (Ciannelli et al., 2008). Comparison of two by two spatial patterns results in many SPAEF outputs. Therefore, the visual SPAEF outputs are illustrated only for monkfish (Fig. 2-5), which is a data-poor species in the study area (Poos et al., 2018). SPAEF metrics of the remaining species are presented briefly, but detailed visual outcomes for each of the other species are available in the Supplementary Material.

To illustrate the effect of chosen grain size, also known as the Modifiable Areal Unit Problem, which exist in spatial analysis including those directed at fisheries management (Jelinski and Wu, 1996; Dark and Bram, 2007; Guisan et al., 2007; Salmivaara et al., 2015), SPAEF was calculated at different raster grid cell sizes. In addition to the above-mentioned default cell size of 0.1 by 0.2 degrees, we chose the coarser grids defined by The International Council for the Exploration of Sea (ICES), whereby statistical rectangles ( 0.5 by 1.0 degrees) are officially used for landings declaration in fisher's logbooks (Hintzen et al., 2018; ICES, 2019), and the finer grid resolution of 0.05 by 0.05 degrees, which have been used for VMS analysis, including in the ICES Working Group on Spatial 


\section{Results}

False presence sampling estimation

192

193

Across all species, size groupings and years the average number of cells with a 'false presence' recorded by TOR was 33 out of the total cell count of 883 when using a grid cell extend of $0.1^{\circ}$ latitude by $0.2^{\circ}$ longitude. The highest number of hauls recorded in SIF passing through a grid cell during 2015-2017 was 31 while the lowest is 1 . The 'false presence' recorded hauls by TOR compared to SIF in the affected grid cells ranged from $3.22 \%$ (small hake) to $100 \%$ (Fig. 1).

The amount of false presence samples (hauls) occurring in TOR differed between species and size class groupings (Fig. 1). Large cod, haddock, lemon sole, large ling, monkfish, pollack, small saithe, small witch flounder and wolffish all had a share of false presence hauls in TOR extending to $100 \%$. Large saithe (up to 15 hauls), small haddock (up to 11 hauls), small hake (up to 12 hauls), small monkfish (up to 31 hauls), small turbot (up to 22 hauls) and small wolffish (up to 25 hauls) had grid cells where this false presence share was out of more than 10 hauls. For all other species and size groupings, the false presence share was applying to less than 10 hauls passing through a false positive cell. Smaller sizes were affected more than the larger sizes by the false presence in TOR, the lack of a finer information assuming small fish to distribute on where they were not found in reality (i.e. in SIF), and this was particularly consistent for monkfish, turbot and wolffish, which showed signs for smaller fish to not be distributed evenly but encountered patchily.

\section{Distribution of landed amount and spatial resolution effect}

Higher SPAEF coefficient was found for monkfish of the size grouping "large" (Fig. 2) compared to monkfish of the size grouping "small" (Fig. 4). Additionally, small grid cells (VMS) produce larger SPAEF output (Fig. 2) compared to large grid cells (ICES square) (Fig. 3). That is, for monkfish in 
2017, the difference in spatial distribution of abundance data between SIF and TOR is higher for the small size grouping of monkfish and also becomes higher if data is aggregated to grid cells with substantial spatial extend (ICES squares) compared to grid cells with a relatively small spatial extent (VMS). The difference in the gradient scale extend between Fig. 2 and Fig. 3 is caused by the aggregation of more samples into each grid cell when the spatial extent of a grid cell is relatively large (ICES squares) compared to relatively small grid cells (VMS).

Cod, haddock, hake, lemon sole, ling, large monkfish, small pollack, saithe, turbot, large witch flounder and large wolffish have SPAEF values were close to 1 when moving from large grid cell sizes $\left(\mathrm{ICES}, 0.5^{\circ}\right.$ by $\left.1.0^{\circ}\right)$ towards small grid cell sizes (VMS, $0.05^{\circ}$ by $\left.0,05^{\circ}\right)($ Fig. 5$)$. Small monkfish, large pollack, small witch flounder, whiting and small wolffish do not show the same tendency. Small monkfish, large pollack and small witch flounder have the main increase in SPAEF value when moving from the largest grid cell size (ICES, $0.5^{\circ}$ by $1.0^{\circ}$ ) to the medium grid cell sizes $\left(0.1^{\circ}\right.$ by $\left.0.2^{\circ}\right)$ and with no apparent increase in SPAEF value going from medium grid cell sizes to the smallest grid cell sizes (VMS, $0.05^{\circ}$ by $0,05^{\circ}$ ). Whiting and small wolffish have no apparent increase in SPAEF value regardless of grid cell sizes, if any change, rather a potential decrease in SPAEF value when moving from large grid cell sizes (ICES, $0.5^{\circ}$ by $1.0^{\circ}$ ) towards small grid cell sizes (VMS, $0.05^{\circ}$ by $0,05^{\circ}$ ). For the species and size groupings with a tendency for an increase in SPAEF value when grid cell sizes are reduced, the main SPAEF metric behind the increased SPAE value is the histogram overlap.

\section{Discussion}

We set out to estimate the potential mismatch that occurs between the fish size composition in the marine-wild fisheries landings data only collected at the individual trip-at-sea level compared to the 
more accurate but less available haul-by-haul level. If redistributing trip-based data to hauls is routinely done, e.g. in Denmark, it remains crucial to examine and confirm if such an approach does provide actual benefits with better estimates. We used opportunistically the data collected by a traceability system (SIF), to make this estimation. However, the data were only available for a subset of the Danish fleet and mainly for large scale demersal trawlers. Our findings show that spatial mismatch in species landings distribution, for instance due to 'false presence' records do arise from the lack of fish body size information at the haul-level. While the mismatch occurs for both large and small size groups, it is more profound for small individuals compared to the large individuals. A possible explanation for this is that in general, the large animal size groupings contain more commercial sizes classes than the small animal size group. Thereby, the information aggregation for larger size classes resemble that of size data collected at a trip-level more than that of the small size classes. The focus of this study was to present the added value of size level at the haul-level and the influence of the geographical resolution chosen for the gridding. Hence, we divided the landings per size group related to a price index to illustrate this added value. If this grouping could appear coarse, our findings already measure a substantial spatial mismatch between the two levels of data resolution, which underpins the influence of the data record level.

Besides, when aggregating data spatially, the specific area size and shape will affect which samples fall within the area and thereby affect the modelled outcome (Guisan et al., 2007; Amoroso et al., 2018a). In theory, this problem could be avoided if each observation is analysed individually (Jelinski and $\mathrm{Wu}, 1996)$. In reality, it is often necessary to aggregate data spatially, e.g. due to the spatial resolution at which data is available and thereby the scale at which it is reasonable to present the data (Salmivaara et al., 2015; Amoroso et al., 2018b; Kroodsma et al., 2018). When choosing the grid cell size for modelling spatial gradient data, a balance between the data record level and the wanted analysis has to be made. 
The outcome of the mismatch analysis for most species and size groups in our study was that the mismatch reduced when the used grid was fine. At first, this might give the impression that grid cell sizes should simply be as small as possible. However, one has to take into account whether the data record level truly allows for pinpointing data to small grid cell sizes. Otherwise, one risk representing data in grid cells that in fact did not contain these records in reality. While most species show a trend towards a higher SPAEF value when grid cell size decrease, the trend is asymptotic with the main increase in degree of overlap achieved when moving from ICES grid cells to lat. $0.1^{\circ}$ by long. $0.2^{\circ}$ grid cell sizes. Additionally, the SPAEF metric which mainly drives this increase is the histogram overlap, meaning that whether a data record truly originate from a grid cell or not is key. That is, whether false presences or absences are inserted into the data when aggregating into grid cells. False absence or methodological absence occurs when the method for data collection is unable to ensure a valid record of absences, whereby data records will have absences where presences should have been observed (Lobo et al., 2010; Barbet-Massin et al., 2012). What our analysis shows (Fig. 1) is that the reverse situation, false presence, may also occur when relying on fisheries dependent data as a source of data. Unlike the false absence, the false presence does not present itself at the species-level as the species was actually caught. If integrating commercial fisheries data with scientific surveys to boost the data availability(Rufener et al., 2018), one risk inducing false presences for fish body size into the distribution of the commercial fisheries data if potential false presences are not accounted for. However, for most species in our analysis, such mismatch can be decreased by using smaller grid cell sizes.

Our findings suggest that beside fish body size records at the haul level, positional data records of fishing activities (effort data), recorded at a fine-scale also will lower the mismatch between size class collected at the haul-level or the trip-level. Fine-scale effort data will allow for finer grid cells because the positional data will represent the correct track line of the fishing vessel better than when coarser 
positional data is used (Needle et al., 2015). Several possibilities to achieve this exist. Since EU 284 fishing vessels are already required to carry VMS, in theory higher precision of effort data could be recorded by simply increasing the ping rate. That is, instead of recording position, speed and course at every 1 to 2 hours, the record could be done at e.g. a 5 minutes interval, just like that of AIS data (Gerritsen et al., 2013; Girard and Du Payrat, 2017). Another option would be to use AIS data from the fishing fleet. One should keep in mind, however, that AIS was developed for security and navigational purposes (IMO, 2019) and therefore skippers can turn AIS equipment on and off as they wish, contrary to the VMS. A third option would be to use electronic monitoring systems that record positional data at at 10 seconds intervals beside recording the ongoing fishing activities with sensors on the fishing gear (Plet-Hansen et al., 2019; van Helmond et al., 2020). Indeed, such electronic monitoring systems, where no video feed is installed but merely sensor and GPS equipment, are already mandatory for certain mussel fisheries in Denmark and Scotland (Nielsen et al., 2014).

In our study, there are a few cases where a higher resolution of spatial effort data does not seem to even makes the spatial allocation mismatch larger. One reason could be that these species and size wolffish or species like cod, haddock or saithe. The lower amount of entries for SPAEF to be run on may simply make the statistics less robust. Whether this is the case or if other factors like different spatial distribution of these species and size classes are at play could be subject for further study.

From an ecological modelling perspective, more data availability of size records are of interest to feed into species distribution models (Elith and Leathwick, 2009) given that fish tend to distribute differently along their life stage while fishing select only a fraction of the overall abundance. On- 
going advances using image recognition could increase the relevance of grading machine data, including data from sea-packing grading machinery, by automating the recording of fish lengths of fish packed in boxes according to the EU commercial size class specifications (Álvarez-Ellacuría et al., 2019). However, because fishers target specific species of commercial interest and use specific fishing techniques which are differently selective over fish body sizes, commercial fishing is by nature a non-random process which means that the fisheries-dependent data cannot be assimilated to stratified random sampling (Smith, 2000; Sims et al., 2008; Madsen and Valentinsson, 2010; Fauconnet and Rochet, 2016). Using such kind of data source for the species distribution modelling would risk biasing the modelling with "false absence" (Barbet-Massin et al., 2012) that may originate from the spatial, temporal and technical selectivity of the commercial fisheries data (Lobo et al., 2010)

In this study, size grouping was based on categories that would relate to fishers' behaviour and thereby fisheries management. This is because the actual size composition of catches and landings is the result of, among other driving factors, the fish quota availability, and the fish price per $\mathrm{kg}$ that influence the targeting behaviour of fishers (Graham et al., 2007; Bourdaud et al., 2018; Robert et $a l ., 2019)$. If species-related non-sized data may be sufficient in informing the possible avoidance of unwanted catches, including fish body size-related information will also help to support other economic drivers for the fishers to optimise their fishing effort spatially. Anticipating the possible size composition of the following hauls holds both ecological and economic values that are likely to influence fishers' decision-making (Little et al., 2009; Bourdaud et al., 2018). Such refined information as used in this study may help in adapting management measures to fit management goals better by accounting for the adaptive behaviour of fishers (Abbott and Haynie, 2012) as well as by supporting the fisheries sector with documentation and tools, easing the compliance with the rules, and eventually minimising the fishing impacts (Hintzen et al., 2018; Bradley et al., 2019; Reid et al., 
2019). It is important to keep in mind though, that the commercial fisheries data used in this study only contain information on landings and thereby lack information for potential discards.

\section{Conclusion}

Our study measured to what extent using commercial fisheries data to deduce the spatial distribution of species and sizes comes with the risk of assuming that fish sizes are distributed to where they are not. We compared data recorded at the haul-level to the same data arranged as if it was recorded at the trip-level. The mismatch was found to be greater for small sizes of a species compared to larger sizes. Using commercial fisheries data records recorded at the trip level may be useful or even necessary. Yet it is important to acknowledge the limitations and potential bias of one's data sources. A clear limitation with the commercial fisheries data used in this study is that it rely solely on records of landings, whereby the influence of potential discards cannot be covered. Our findings do however suggest that the potential bias induced by redistributing sizes recorded at the trip-level onto the haullevel could be decreased if the positional data for the actual fishing activities are collected at an interval allowing for refined fishing effort data. For certain species, however, fine-scale effort data did not help, while size information recorded at the haul level still did. While this might be influence by low landing volumes, other factors such as different spatial distribution of these species could be a potential reason too. Further studies are needed to investigate this.

\section{Supplementary material}

The following supplementary material is available at ICESJMS online: Detailed SPAEF outcomes for the 12 species divided by size grouping for the three investigated grid cell sizes.

\section{Acknowledgements}


This work has received funding from the Horizon 2020 Programme under the project DiscardLess grant agreement number 633680 and also from the European Maritime and Fisheries Foundation and the Ministry of Environment and Food of Denmark (grant ID: 33113-B-19-150; project: Ecosystem based Management of fish stocks in the North Sea, ECOMAN). This support is gratefully acknowledged. The authors thankfully acknowledge the data sharing provided by fishers as well as DFPO and the Danish Fisheries Agency. This is gratefully acknowledged.

\section{Date availability}

The data underlying this article cannot be shared publicly due to the privacy of fishers and data protection of personal information. The data will be shared on reasonable request to the corresponding author.

\section{References}

Abbott, J. K., and Haynie, A. C. 2012. What are we protecting? Fisher behavior and the unintended consequences of spatial closures as a fishery management tool. Ecological Applications, 22: $762-777$.

Álvarez-Ellacuría, A., Palmer, M., Catalán, I. A., and Lisani, J.-L. 2019. Image-based, unsupervised estimation of fish size from commercial landings using deep learning. ICES Journal of Marine Science.

Amoroso, R. O., Pitcher, C. R., Rijnsdorp, A. D., McConnaughey, R. A., Parma, A. M., Suuronen, P., Eigaard, O. R., et al. 2018a. Bottom trawl fishing footprints on the world's continental shelves. Proceedings of the National Academy of Sciences of the United States of America, 115: E10275-E10282. 
Amoroso, R. O., Parma, A. M., Pitcher, C. R., McConnaughey, R. A., and Jennings, S. 2018b. Comment on "Tracking the global footprint of fisheries". Science, 361: eaat6713. http://www.ncbi.nlm.nih.gov/pubmed/30139846.

Barbet-Massin, M., Jiguet, F., Albert, C. H., and Thuiller, W. 2012. Selecting pseudo-absences for species distribution models: How, where and how many? Methods in Ecology and Evolution, 3: $327-338$.

Bastardie, F., Nielsen, J. R., Ulrich, C., Egekvist, J., and Degel, H. 2010. Detailed mapping of fishing effort and landings by coupling fishing logbooks with satellite-recorded vessel geolocation. Fisheries Research, 106: 41-53. Elsevier B.V. http://dx.doi.org/10.1016/j.fishres.2010.06.016.

Batsleer, J., Hamon, K. G., van Overzee, H. M. J., Rijnsdorp, A. D., and Poos, J. J. 2015. Highgrading and over-quota discarding in mixed fisheries. Reviews in Fish Biology and Fisheries, 25: 715-736. Springer International Publishing.

Bergsson, H., Plet-Hansen, K. S., Jessen, L. N., Jensen, P., and Bahlke, S. Ø. 2017. Final Report on Development and usage of REM systems along with electronic data transfer as a measure to monitor compliance with the Landing Obligation - 2016. 61 pp pp.

Borges, L., and Penas Lado, E. 2019. Discards in the Common Fisheries Policy: The Evolution of the Policy. In The European Landing Obligation - reducing discards in complex, multi-species and multi-jurisdictional fisheries, pp. 27-47. Ed. by S. S. Uhlmann, C. Ulrich, and S. J. Kennelly. Springer International Publishing AG, part of Springer Nature, Dordrecht.

Bourdaud, P., Travers-trolet, M., Vermard, Y., Cormon, X., and Marchal, P. 2017. Inferring the annual, seasonal, and spatial distributions of marine species from complementary research and commercial vessels ' catch rates. ICES Journal of Marine Science, 74: 2415-2426. 
Bourdaud, P., Travers-Trolet, M., Vermard, Y., and Marchal, P. 2018. Improving the interpretation of fishing effort and pressures in mixed fisheries using spatial overlap metrics. Canadian Journal of Fisheries and Aquatic Sciences: 1-11. http://www.nrcresearchpress.com/doi/10.1139/cjfas-2017-0529.

Bowering, W. R. 1976. Distribution, Age and Growth, and Sexual Maturity of Witch Flounder (Glyptocephalus cynoglossus) in Newfoundland Waters. Journal of the Fisheries Research Board of Canada, 33: 1574-1584.

Bradley, D., Merrifield, M., Miller, K. M., Lomonico, S., Wilson, J. R., and Gleason, M. G. 2019. Opportunities to improve fisheries management through innovative technology and advanced data systems. Fish and Fisheries: 1-20. http://doi.wiley.com/10.1111/faf.12361.

Catchpole, T. L., Elliott, S., Peach, D., Mangi, S. C., and Gray, T. S. 2018. How to deal with the EU landing obligation: Lessons from an English discard ban sea trial. ICES Journal of Marine Science, 75: 270-278.

Ciannelli, L., Fauchald, P., Chan, K. S., Agostini, V. N., and Dingsør, G. E. 2008. Spatial fisheries ecology: Recent progress and future prospects. Journal of Marine Systems, 71: 223-236.

Dark, S. J., and Bram, D. 2007. The modifiable areal unit problem (MAUP) in physical geography. Progress in Physical Geography, 31: 471-479.

Elith, J., and Leathwick, J. R. 2009. Species distribution models: ecological explanation and prediction across space and time. Annual Review of Ecology, Evolution, and Systematics, 40: 677-697. http://www.annualreviews.org/doi/abs/10.1146/annurev.ecolsys.110308.120159.

EU. 1996. COUNCIL REGULATION (EC) No 2406/96 of 26 November 1996 laying down common marketing standards for certain fishery products. Official Journal of the European 
EU. 2011. COMMISSION IMPLEMENTING REGULATION (EU) No 404/2011 of 8 April 2011 laying down detailed rules for the implementation of Council Regulation (EC) No 1224/2009 establishing a Community control system for ensuring compliance with the rules of the Common Fish. Official Journal of the European Union, L 112/1.

EU. 2012. COMMISSION IMPLEMENTING REGULATION (EU) No 433/2012 of 23 May 2012 laying down detailed rules for the application of Regulation (EU) No 1236/2010 of the European Parliament and of the Council laying down a scheme of control and enforcement applicable in t. Official Journal of the European Union, L 136/41.

EU. 2013. REGULATION (EU) No 1380/2013 OF THE EUROPEAN PARLIAMENT AND OF THE COUNCIL of 11 December 2013 on the Common Fisheries Policy, amending Council Regulations (EC) No 1954/2003 and (EC) No 1224/2009 and repealing Council Regulations (EC) No 2371/2002 and (EC.

EU. 2016. COMMISSION IMPLEMENTING DECISION (EU) 2016/1701 of 19 August 2016 laying down rules on the format for the submission of work plans for data collection in the fisheries and aquaculture sectors.

Fauconnet, L., and Rochet, M. J. 2016. Fishing selectivity as an instrument to reach management objectives in an ecosystem approach to fisheries. Marine Policy, 64: 46-54. Elsevier. http://dx.doi.org/10.1016/j.marpol.2015.11.004.

FishBase. 2019a. Pollack. https://www.fishbase.in/summary/34 (Accessed 22 February 2019).

FishBase. 2019b. Atlantic wolffish. https://www.fishbase.se/summary/2501 (Accessed 22 February 2019). 
Gerritsen, H., and Lordan, C. 2011. Integrating vessel monitoring systems (VMS) data with daily catch data from logbooks to explore the spatial distribution of catch and effort at high resolution. ICES Journal of Marine Science, 68: 245-252.

Gerritsen, H. D., Minto, C., and Lordan, C. 2013. How much of the seabed is impacted by mobile fishing gear? Absolute estimates from Vessel Monitoring System (VMS) point data. ICES Journal of Marine Science, 70: 523-531.

Girard, P., and Du Payrat, T. 2017. An inventory of new technologies in fisheries. https://www.oecd.org/greengrowth/GGSD_2017_Issue Paper_New technologies in Fisheries_WEB.pdf.

Graham, N., Ferro, R. S. T., Karp, W. a, and MacMullen, P. 2007. Fishing pratice, gear desing, and the ecosystem approach - three case studies demonstrating the effect of management strategy on gear selectivity and discards. ICES Journal of Marine Science, 64: 744-750.

Guisan, A., Graham, C. H., Elith, J., Huettmann, F., Dudik, M., Ferrier, S., Hijmans, R., et al. 2007. Sensitivity of predictive species distribution models to change in grain size. Diversity and Distributions, 13: 332-340.

Gunnarsson, Á., Skírnisdóttir, S., Daníelsdóttir, A. K., and Porsteinsson, V. 2013. Genetic diversity, growth, maturity and migration of the Atlantic wolffish (Anarhichas lupus L.). http://www.matis.is/media/matis/utgafa/09-13_Erfdabreytileiki.pdf.

Gupta, H. V., Clark, M. P., Vrugt, J. A., Abramowitz, G., and Ye, M. 2012. Towards a comprehensive assessment of model structural adequacy. Water Resources Research, 48: 1-16.

Hilborn, R. 2007. Managing fisheries is managing people: what has been learned? Fish and Fisheries, 8: 285-296. 
Hintzen, N. T., Bastardie, F., Beare, D., Piet, G., Ulrich, C., Deporte, N., Egekvist, J., et al. 2012. VMStools: Open source software for the processing, analysis and visualization of fisheries logbook and VMS data. Fisheries Research, 115-116: 31-43.

Hintzen, N. T., Aarts, G., and Rijnsdorp, A. D. 2018. Persistence in the fine-scale distribution and spatial aggregation of fishing. ICES Journal of Marine Science. https://academic.oup.com/icesjms/advance-article/doi/10.1093/icesjms/fsy144/5232289.

Hoff, A., Frost, H., Andersen, P., Prellezo, R., Rueda, L., Triantaphyllidis, G., Argyrou, I., et al. 2019. Potential Economic Consequences of the Landing Obligation. In The European Landing Obligation Reducing Discards in Complex, Multi-Species and Multi-Jurisdictional Fisheries, pp. 109-128. Ed. by S. S. Uhlmann, C. Ulrich, and S. J. Kennelly. Springer Open.

ICES. 2014a. ICES FishMap species factsheet- Cod. Copenhagen.

ICES. 2014b. ICES FishMap species factsheet-Haddock. Copenhagen. http://www.ices.dk/exploreus/projects/EU-RFP/EU Repository/ICES FIshMap/ICES FishMap species factsheethaddock.pdf.

ICES. 2014c. ICES FishMap species factsheet- Saithe. Copenhagen. http://www.ices.dk/exploreus/projects/EU-RFP/EU Repository/ICES FIshMap/ICES FishMap species factsheetSaithe.pdf.

ICES. 2014d. ICES FishMap species factsheet- Whiting. Copenhagen. http://www.ices.dk/exploreus/projects/EU-RFP/EU Repository/ICES FIshMap/ICES FishMap species factsheetwhiting.pdf.

ICES. 2018. Report of the Working Group on Spatial Fisheries Data (WGSFD). Aberdeen. 79 pp. pp. 
ICES. 2019. ICES statistical rectangles. https://www.ices.dk/marine-data/maps/Pages/ICESstatistical-rectangles.aspx (Accessed 5 April 2019).

IMO. 2019. Automatic Identification System (AIS). http://www.imo.org/en/OurWork/Safety/Navigation/Pages/AIS.aspx (Accessed 24 June 2019).

James, K. M., Campbell, N., Viðarsson, J. R., Vilas, C., Plet-Hansen, K. S., Borges, L., PérezBouzada, J., et al. 2019. Tools and technologies for the monitoring, control and surveillance of unwanted catches. In The European Landing Obligation - reducing discards in complex, multispecies and multi-jurisdictional fisheries, pp. 363-382. Ed. by S. S. Uhlmann, C. Ulrich, and S. J. Kennelly. Springer International Publishing AG, part of Springer Nature, Dordrecht.

Jelinski, D. E., and Wu, J. 1996. The modifiable areal unit problem and implications for landscape ecology. Landscape Ecology, 11: 129-140.

Koch, J., Demirel, M. C., and Stisen, S. 2018. The SPAtial EFficiency metric (SPAEF): Multiplecomponent evaluation of spatial patterns for optimization of hydrological models. Geoscientific Model Development, 11: 1873-1886.

Krause, P., Boyle, D. P., and Bäse, F. 2005. Comparison of different efficiency criteria for hydrological model assessment. Advances in Geosciences, 5: 89-97.

Kroodsma, D. A., Mayorga, J., Hochberg, T., Miller, N. A., Boerder, K., Ferretti, F., Wilson, A., et al. 2018. Response to Comment on 'Tracking the global footprint of fisheries'. Science, 361: eaat7789. http://www.ncbi.nlm.nih.gov/pubmed/30139846.

Little, A. S., Needle, C. L., Hilborn, R., Holland, D. S., and Marshall, C. T. 2015. Real-time spatial management approaches to reduce bycatch and discards: Experiences from Europe and the United States. Fish and Fisheries, 16: 576-602. 
Little, L. R., Punt, A. E., Mapstone, B. D., Begg, G. a., Goldman, B., and Williams, A. J. 2009. An agent-based model for simulating trading of multi-species fisheries quota. Ecological Modelling, 220: 3404-3412.

Lobo, J. M., Jiménez-Valverde, A., and Hortal, J. 2010. The uncertain nature of absences and their importance in species distribution modelling. Ecography, 33: 103-114.

Macdonald, P., Batts, L., and Henderson, L. 2017. Data limited fish stocks in the northern North Sea. https://www.nafc.uhi.ac.uk/research/fisheries/data-limited-stocks/.

Madsen, N., and Valentinsson, D. 2010. Use of selective devices in trawls to support recovery of the Kattegat cod stock: A review of experiments and experience. ICES Journal of Marine Science, 67: 2042-2050.

Miljø- og Fødevareministeriet. 2014. BEK nr 1593 af 17/12/2014 Bekendtgørelse om føring af logbog m.v. BEK nr 1593 af 17/12/2014. Denmark. https://www.retsinformation.dk/pdfPrint.aspx?id=167031.

Mortensen, L. O., Ulrich, C., Hansen, J., and Hald, R. 2018. Identifying choke species challenges for an individual demersal trawler in the North Sea , lessons from conversations and data analysis. Marine Policy, 87: 1-11. Elsevier Ltd. https://doi.org/10.1016/j.marpol.2017.09.031.

Needle, C. L., Dinsdale, R., Buch, T. B., Catarino, R. M. D., Drewery, J., and Butler, N. 2015. Scottish science applications of Remote Electronic Monitoring. ICES Journal of Marine Science, $72:$ 1214-1229.

Nielsen, P., Canal-Vergés, P., Geitner, K., and Nielsen, Carsten Fomsgaard; Petersen, J. K. 2014. Konsekvensvurdering af fiskeri på blåmuslinger og søstjerner i Løgstør Bredning 2014/2015. DTU Aqua-rapport, 285-2014. 
O’Neill, F. G., Feekings, J., Fryer, R. J., Fauconnet, L., and Afonso, P. 2019. Discard Avoidance by Improving Fishing Gear Selectivity: Helping the Fishing Industry Help Itself. In The European Landing Obligation Reducing Discards in Complex, Multi-Species and Multi-Jurisdictional Fisheries, pp. 279-296.

Ono, K., Holland, D. S., and Hilborn, R. 2013. How does species association affect mixed stock fisheries management? A comparative analysis of the effect of marine protected areas, discard bans, and individual fishing quotas. Canadian Journal of Fisheries and Aquatic Sciences, 70: 1792-1804. dx.doi.org/10.1139/cjfas-2013-0046.

Pennino, M. G., Conesa, D., López-Quílez, A., Munoz, F., Fernández, A., and Bellido, J. M. 2016. Fishery-dependent and -independent data lead to consistent estimations of essential habitats. ICES Journal of Marine Science, 73: 2302-2310.

Plet-Hansen, K. S., Larsen, E., Mortensen, L. O., Nielsen, J. R., and Ulrich, C. 2018. Unravelling the scientific potential of high resolution fishery data. Aquatic Living Resources, 31: $14 \mathrm{pp}$.

Plet-Hansen, K. S., Bergsson, H., and Ulrich, C. 2019. More data for the money: Improvements in design and cost efficiency of electronic monitoring in the Danish cod catch quota management trial. Fisheries Research, 215: 114-122.

Poos, J.-J., De Oliveira, J., Ulrich, C., Brunel, T., Plet-Hansen, K. S., Mildenberger, T., Nielsen, J. R., et al. 2018. Study on the Approaches to Management for Data-Poor Stocks in Mixed Fisheries : DRuMFISH. Brussels. https://publications.europa.eu/en/publication-detail//publication/690ce56f-f2c2-11e8-9982-01aa75ed71a1/language-en/format-PDF/source81865252.

Reid, D. G., Calderwood, J., Afonso, P., Bourdaud, P., Fauconnet, L., González-irusta, J. M., Mortensen, L. O., et al. 2019. The Best Way to Reduce Discards Is by Not Catching Them! In 

The European Landing Obligation: Reducing Discards in Complex, Multi-Species and MultiJurisdictional Fisheries, pp. 257-278. Ed. by S. S. Uhlmann, C. Ulrich, and J. Kennelly, Steven. Springer, Cham.

Robert, M., Calderwood, J., Radford, Z., Catchpole, T., Reid, D. G., and Pawlowski, L. 2019. Spatial distribution of discards in mixed fisheries: species trade-offs, potential spatial avoidance and national contrasts. Reviews in Fish Biology and Fisheries, 29: 917-934. Springer International Publishing. https://doi.org/10.1007/s11160-019-09581-z.

Robinson, L. A., Greenstreet, S., Reiss, H., and Callaway, R. 2010. Length - weight relationships of 216 North Sea benthic invertebrates and fish. Journal of the Marine Biological Association of the UK, 90.

Rufener, M.-C., Kristensen, K., Nielsen, J. R., Dinesen, G. E. ., and Bastardie, F. 2018. Coupling commercial fisheries and survey data: a practical solution to boost the amount of information in data-poor context. Abstract from IIFET 2018, Seattle, United States.

Salmivaara, A., Porkka, M., Kummu, M., Keskinen, M., Guillaume, J. H. A., and Varis, O. 2015. Exploring the modifiable areal unit problem in spatial water assessments: A case of water shortage in Monsoon Asia. Water, 7: 898-917.

Salomon, M., Markus, T., and Dross, M. 2014. Masterstroke or paper tiger - The reform of the EU's Common Fisheries Policy. Marine Policy, 47: 76-84. Elsevier. http://dx.doi.org/10.1016/j.marpol.2014.02.001.

Silva, J. F., Ellis, J. R., and Ayers, R. A. 2013. Length-weight relationships of marine fish collected from around the British Isles. 109pp pp. https://www.cefas.co.uk/publications/techrep/TechRep150.pdf. 
Sims, M., Cox, T., and Lewison, R. 2008. Modeling Spatial Patterns in Fisheries Bycatch: Improving Bycatch Maps to Aid Fisheries Management. Ecological Applications, 18: 649661.

Sjöberg, E. 2012. Pricing on the fish market - Does size matter? Marine Resource Economics, 30: 277-296.

Smith, M. D. 2000. Spatial Search and Fishing Location Choice. American Journal of Agricultural Economics, 82: 1198-1206.

STECF. 2018. Scientific, Technical and Economic Committee for Fisheries (STECF) - 57th Plenary Meeting Report (PLEN-18-01). Publications Office of the European Union, Luxembourg, JRC111800. Luxembourg.

Stratoudakis, Y., Fryer, R. J., and Cook, R. M. 1998. Discarding practices for commercial gadoids in the North Sea. Canadian Journal of Fisheries and Aquatic Sciences, 55: 1632-1644.

The Safina Center. 2019. TURBOT- NORTHEAST ATLANTIC. http://safinacenter.org/documents/2013/06/turbot-northeast-atlantic-full-species-report.pdf/.

Ulrich, C., Dalskov, J., Egekvist, J., Håkansson, K. B., and Olesen, H. J. 2013. Behind the shine : An appraisal of five years of Danish CCTV trials .: 2012-2013.

van Helmond, A. T. M., Mortensen, L. O., Plet-Hansen, K. S., Ulrich, C., Needle, C. L., Oesterwind, D., Kindt-Larsen, L., et al. 2020. Electronic monitoring in fisheries: Lessons from global experiences and future opportunities. Fish and Fisheries, 21: 162- 189.

Villasante, S., Antelo, M., Christou, M., Fauconnet, L., Frangoudes, K., Maynou, F., Morato, T., et al. 2019. The Implementation of the Landing Obligation in Small-Scale Fisheries of Southern European Union Countries. In The European Landing Obligation Reducing Discards in 

C. Ulrich, and S. J. Kennelly. Springer Open. 
601 Table 1. Total Degrees of Freedom (DF), r-squared $\left(r^{2}\right)$ and r-squared for data with log-

602 transformation (log-transformed $\mathrm{r}^{2}$ ) for the 12 species identified as being well in accordance with 603 sales slips and logbook records for the six vessels in the years 2015-2017.

\begin{tabular}{lccc} 
Species & $\mathbf{D F}$ & $\mathbf{r}^{\mathbf{2}}$ & log-trans $\mathbf{r}^{\mathbf{2}}$ \\
\hline Cod & 3510 & 0.871 & 0.841 \\
\hline Haddock & 1589 & 0.884 & 0.877 \\
\hline Hake & 1503 & 0.810 & 0.935 \\
\hline Lemon sole & 1549 & 0.916 & 0.944 \\
\hline Ling & 1058 & 0.974 & 0.944 \\
\hline Monkfish & 2382 & 0.944 & 0.928 \\
\hline Pollack & 824 & 0.962 & 0.916 \\
\hline Saithe & 1617 & 0.879 & 0.931 \\
\hline Turbot & 1653 & 0.894 & 0.931 \\
\hline Witch flounder & 1653 & 0.908 & 0.865 \\
\hline Whiting & 167 & 0.950 & 0.944 \\
\hline Wolffish & 1161 & 0.916 & \\
\hline
\end{tabular}


605 Table 2. Division by size class and kg between small and large grouping.

\begin{tabular}{lllll} 
Species & Division & Number of size & Number of size & Rationale \\
& small/large & classes in size & classes in size & \\
& & group small & group large & \\
\hline Cod & Size class 3 & 2 & 4 & (Ulrich et al., 2013) \\
& $(>=2.00 \mathrm{~kg})$ & & 2 & (Stratoudakis et al., \\
& Size class 2 & 2 & & 1998; Bergsson et \\
& $(>=0.57 \mathrm{~kg})$ & & $a l .$, 2017)
\end{tabular}

\begin{tabular}{lllll}
\hline Hake & Size class 2 & 2 & 3 & (Bergsson et al. \\
& $(>=1.20 \mathrm{~kg})$ & & $2017)$ \\
\hline Lemon sole & Size class 2 & 1 & 2 & Prices 2015-2017 \\
& $(>=0.35 \mathrm{~kg})$ & & & \\
\hline Ling & Size class 2 & 1 & 2 & Prices 2015-2017 \\
& $(>=3.00 \mathrm{~kg})$ & & & \\
\hline Monkfish & Size class 4 & 1 & 4 & Prices 2015-2017 \\
& $(>=1.00 \mathrm{~kg})$ & & & \\
\hline Pollack & Size class 2 & 2 & 2 & Prices 2015-2017 \\
& $(>=3.00 \mathrm{~kg})$ & & & (Bergsson et al., \\
\hline Saithe & Size class 3 & 1 & 3 & Prices 2015-2017 \\
& $(>=1.5 \mathrm{~kg})$ & & &
\end{tabular}




\begin{tabular}{lllll} 
Witch flounder & Size class 2 & 1 & 2 & Prices 2015-2017 \\
& $(>=0.3 \mathrm{~kg})$ & & & \\
\hline Whiting & Size class 2 & 2 & 2 & (Stratoudakis et al., \\
& $(>=0.35 \mathrm{~kg})$ & & al., 2017) \\
& & & & Prices 2015-2017 \\
\hline Wolffish & Size class 3 & 1 & 2 &
\end{tabular}

606

607 


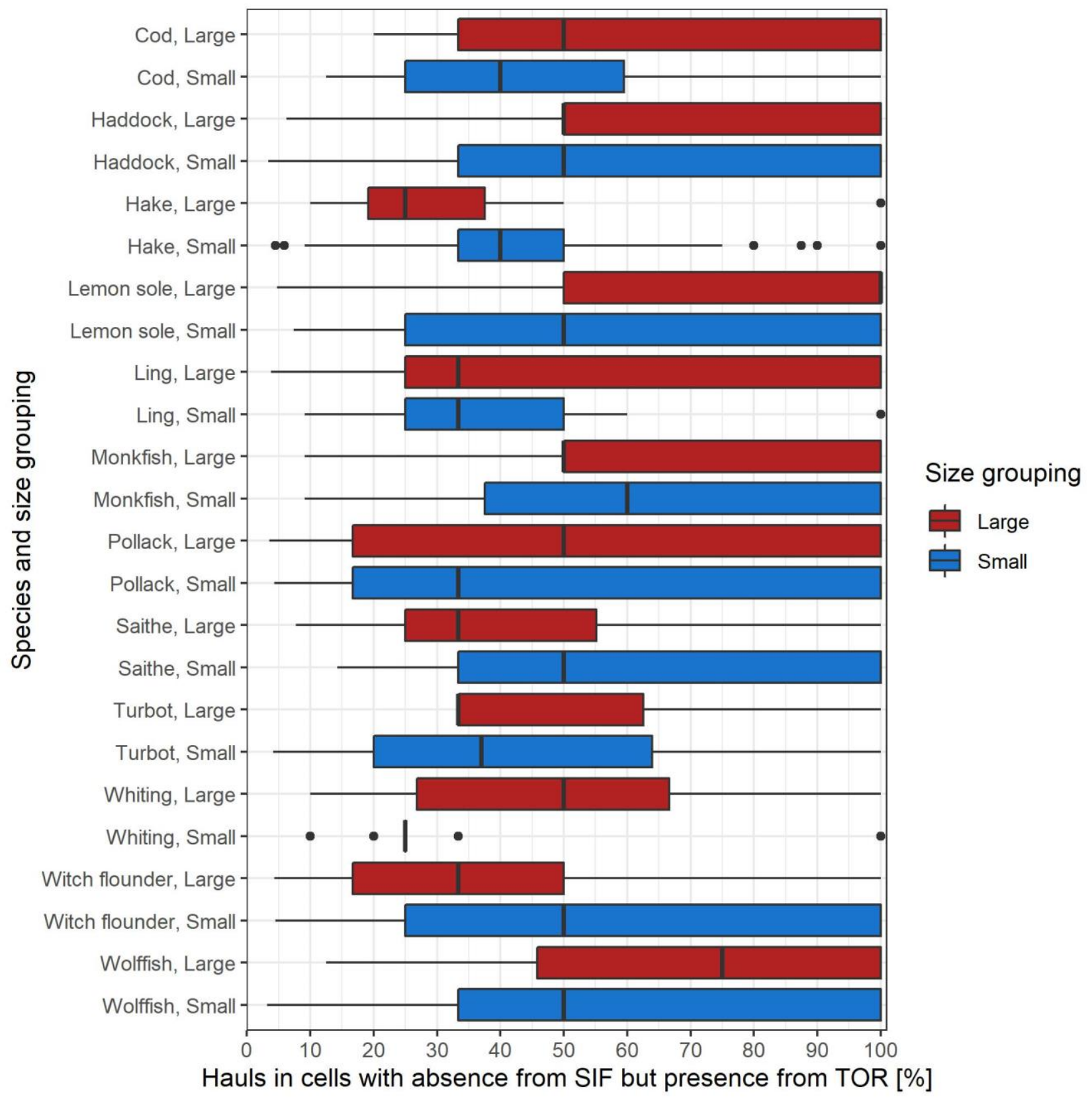

610 Figure 1. The box-and-whiskey plot of the share of 'false presence' samples (hauls) in grid cells of

$6110.1^{\circ}$ latitude by $0.2^{\circ}$ longitude where species are absent in SIF but present in TOR. The $\mathrm{x}$-axis

612 shows species and size grouping, the y-axis shows the percentile share of hauls with a 'false

613 positive' record in TOR out of the total amount of hauls passing through a cell. 

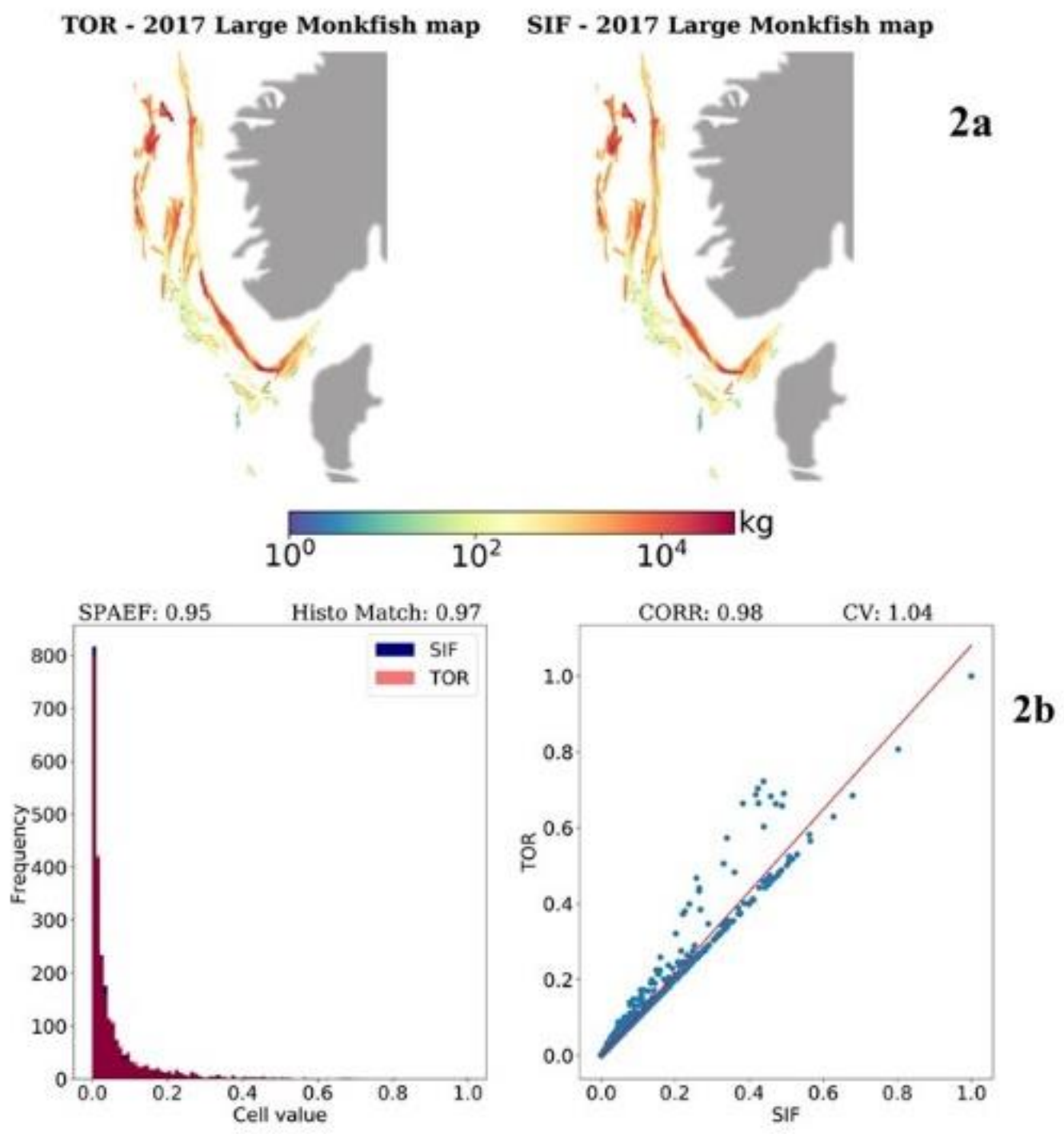

614

615 Figure 2. SPAEF output when using VMS grid cell sizes $\left(0.05^{\circ}\right.$ by $\left.0.05^{\circ}\right)$ for large monkfish in 616 2017. Subplot a) compares the spatial overlap for TOR and SIF. Gradient colour is the amount of 617 monkfish in $\mathrm{kg}$ associated with each grid cell on a logarithmic scale. Grey area is a sketch of 618 western Norway and Denmark. Subplot b) compares the histogram overlap and the correlation 619 between TOR and SIF. SPAEF coefficient is 0.95 , histogram overlap is 0.97 , Pearson correlation is $620 \quad 0.98$ and $\mathrm{CV} / \mathrm{CV}$ is 1.04. 

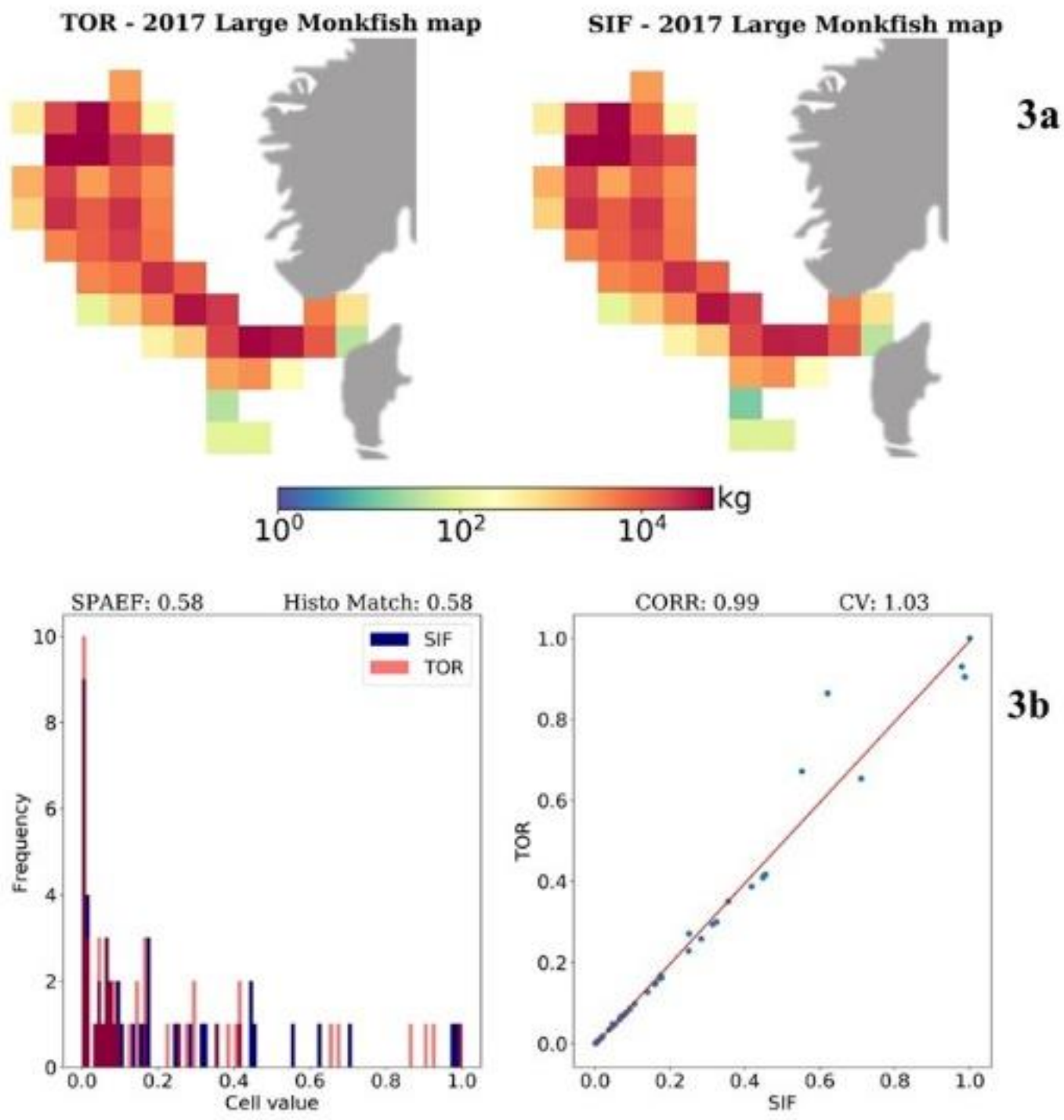

622

623 Figure 3. SPAEF output when using ICES grid cell sizes $\left(0.5^{\circ}\right.$ by $\left.1.0^{\circ}\right)$ for large monkfish in 2017.

624 Subplot a) compares the spatial overlap for TOR and SIF. Gradient colour is the amount of

625 monkfish in $\mathrm{kg}$ associated with each grid cell on a logarithmic scale. Grey area is a sketch of

626 western Norway and Denmark. Subplot b) compares the histogram overlap and the correlation

627 between TOR and SIF. SPAEF coefficient is 0.58 , histogram overlap is 0.58 , Pearson correlation is 628 0.99 and $\mathrm{CV} / \mathrm{CV}$ is 1.03 . 


\section{TOR - 2017 Small Monkfish map SIF - 2017 Small Monkfish map}
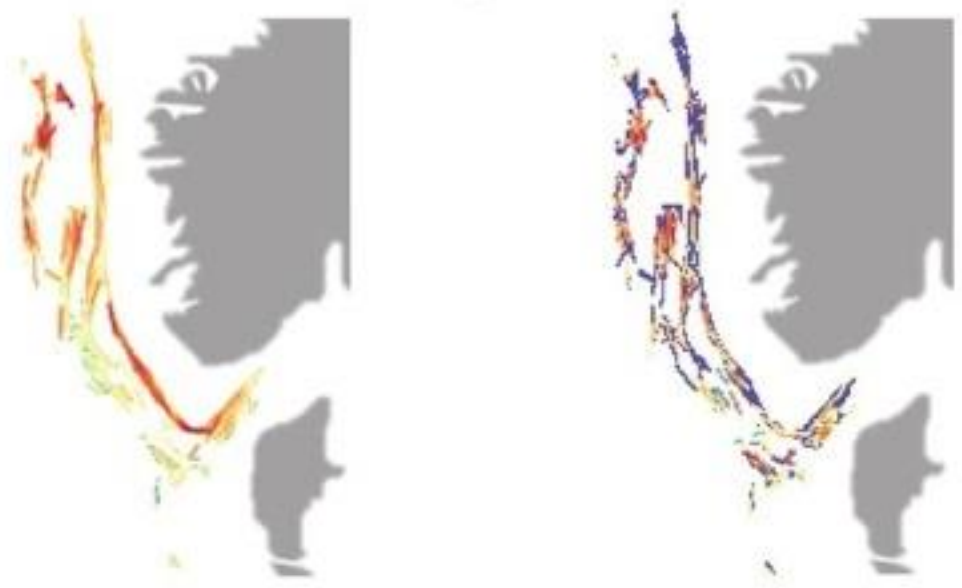

4a

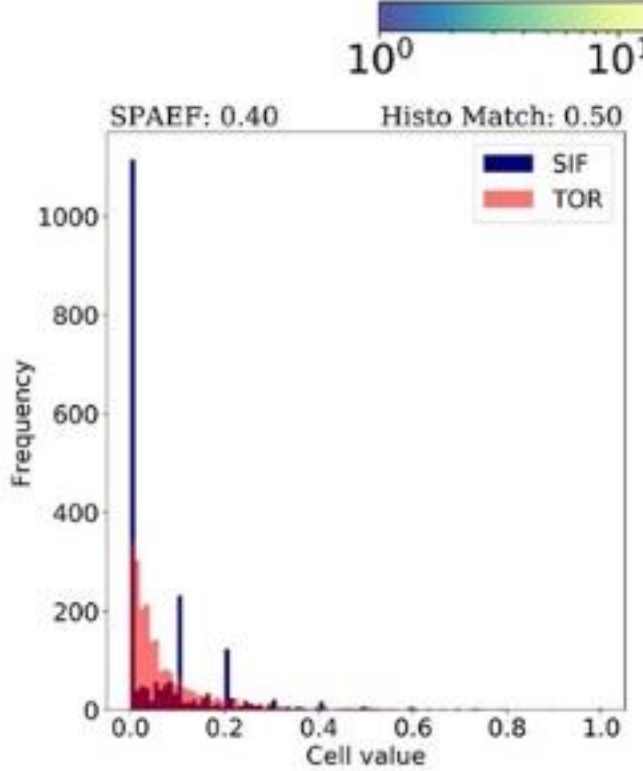

630

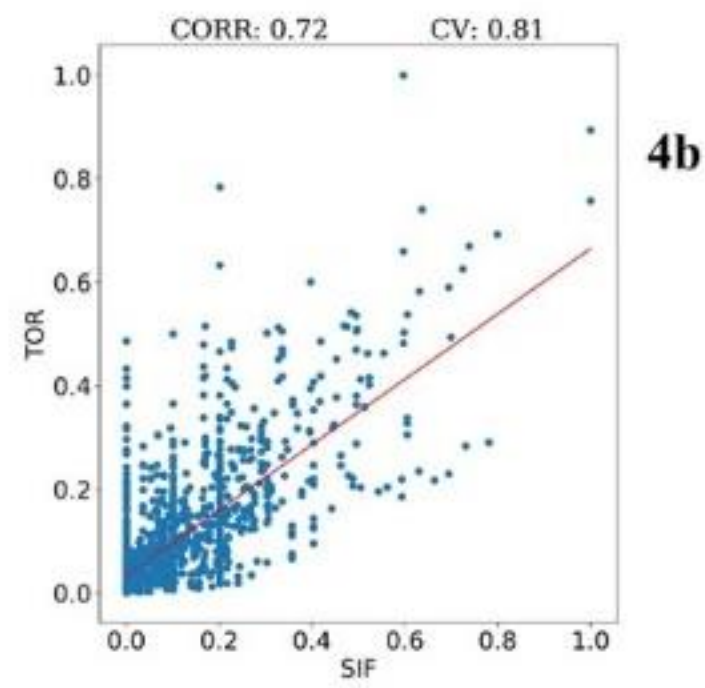

631 Figure 4. SPAEF output when using VMS grid cell sizes $\left(0.05^{\circ}\right.$ by $\left.0.05^{\circ}\right)$ for small monkfish in 2017. Subplot a) compares the spatial overlap for TOR and SIF. Gradient colour is the amount of

633 monkfish in $\mathrm{kg}$ associated with each grid cell on a logarithmic scale. The grey area is a sketch of

634 western Norway and Denmark. Subplot b) compares the histogram overlap and the correlation

635 between TOR and SIF. SPAEF coefficient is 0.40 , histogram overlap is 0.50 , Pearson correlation is 636 0.72 and $\mathrm{CV} / \mathrm{CV}$ is 0.81 . 


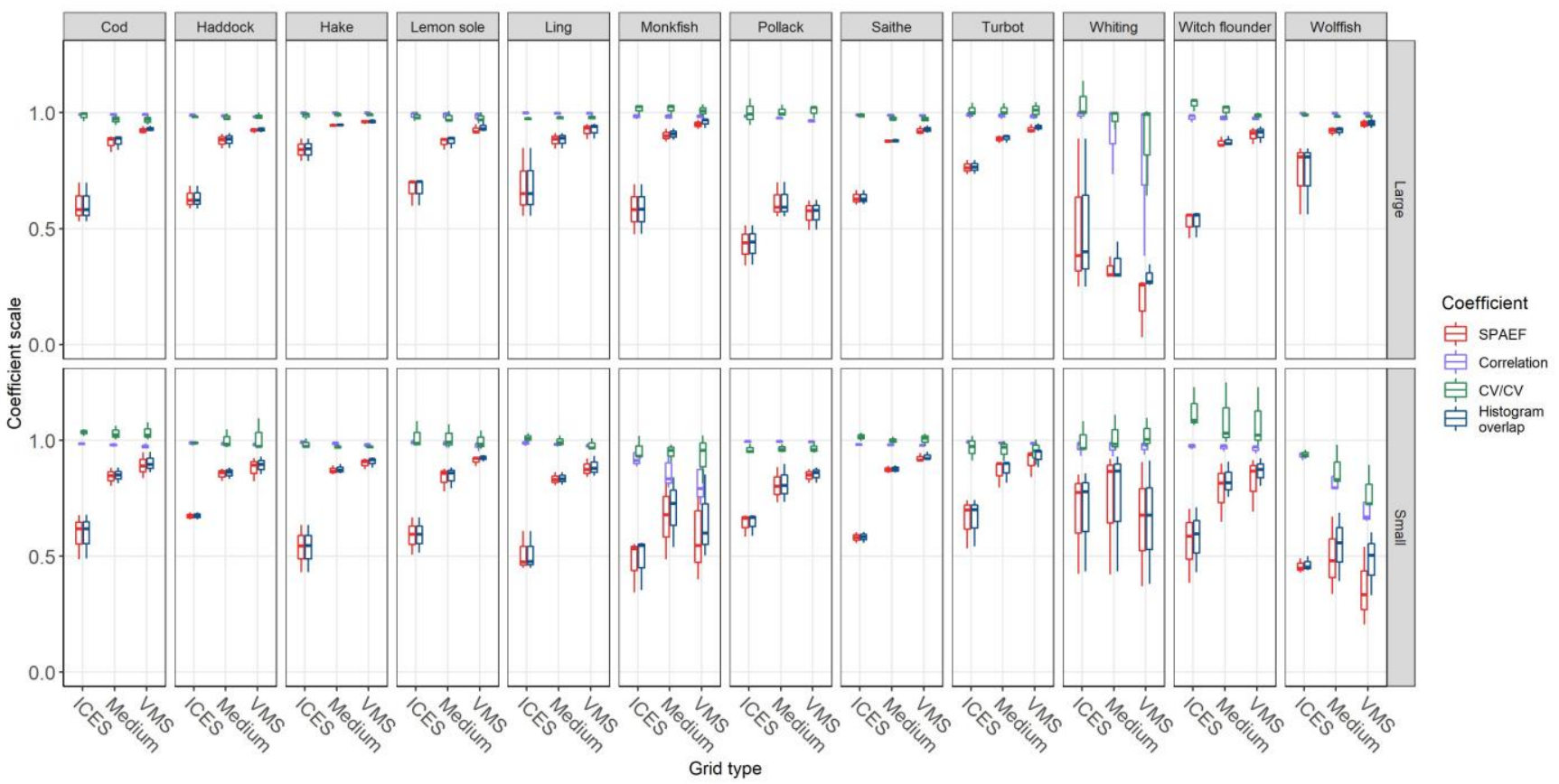

639 Figure 5. Box-and-whiskers plot of outcome for SPAEF and its three composite coefficients for the 640 large and small size group of the 12 species by the three grid cell sizes for the years 2015-2017. A 641 SPAEF at 1 means full match between the two trip-based TOR and haul-based SIF spatial patterns. 